\title{
発語時下顎運動に咬合高径の変化が及ぼす影響に 関する研究
}

Effect of Change in Occlusal Vertical Dimension on Mandibular Movements during Speech

○小河弘枝、山口善一、荊木理惠子、吉岡慎郎、桑原俊也、高島史男、丸山剛郎

Hiroe Ogawa, Yoshikazu Yamaguchi, Rieko Ibaraki, Chikao Yoshioka, Toshiya Kuwahara,

Fumio Takashima and Takao Maruyama

大阪大学齿学部歯科補緅学第一講座

Department of Fixed Prosthodontics, Osaka University Faculty of Dentistry

1 粕 言

発語は咀噮、燕下とともに頞口腔のもつ重要な機能

で、䫟口腔系を搆成する種々の器官の協調によって営 まれるものである。発語における下䫈運動は、頻口腔 系諸器官の機能状態が反映されているものと考えられ、 末梢のフィードバックと中枢の制御により遂行される 下㯋運動のなかでも重要な機能運動の一つである"。

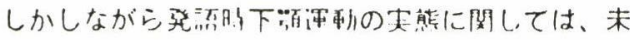
だ不明な点が多い。

咬合の概念は従来、静的、機械的、解剖学的なもの から近年、動的、機能的、生理学的なものへと变化し てきており、この観点から発語時下旗運動に咬合が及 ぼす影響を明らかにすることは重要であると考えられ る。そこで当教室では発語時下䪽運動を動的かつ生理 的に捉え、その実態を明らかにするために被験文を作 成( 2)、恒常性 ${ }^{3.4)}$ 、個性正常咬合者の発語時下㯋運 動の検討を行な(4)、さらに咬合異常が発語時下㯋運 動に及ぼす影響について検討を行ってきだ、5)。また 三次元的に構成される咬合は、オクルーザルガイダン スと呼ばれる前後的、左右的、垂直的な3つの要素に 分類され、垂直的ガイダンスを決定する要素には咬合 高径が考えられる6.7.8)。

咬合高径は、歯根膜のみでなく頻関節、咀嚼筋から の感賞入力をも末梢にフィードバックさせた下鿓運動 のガイダンスである ${ }^{7,8)}$ 。発語時下鿓運動と咬合高径 との関連性については、従来より $\mathrm{s}$ 音等の単音の下䋶 運動との関連性が論じられてきだ.10.11)。しかしな がら、被験文朗読時の発語時下頢運動之咬合高径亡の 関連性についての報告は少なく未だ不明な点が多いの が現状である。

そこで、本研究は発語時下䋶運動に咬合高径が及ほ
す影響を明らかにすることを目的として、咬合高径の 挙上による発語時下㯋運動の変化について検討を行な った。

11 方 法

\section{1 被験者}

被験者として、額口腔機能に特に異常を認めず、歯 の欠損や著しい不正咬合を有しない、いわ洛性正 常咬合者で側方限界運動が犬歯誘導である者 5 名（年 齢24 28歳、平均年齡25. 2歳、男性 4名、女性 1名) を選択した。

\section{2 実験装置}

垂直的ガイダンス設定装置（以下装置とする）とし て上鶜全歯列咬合面に可及的に本来の咬合面形㮩を再 現したアンレー型装置を金銀パラジウム合金にて作製 した。装置による咬合挙上量は、被験者全員の安静空

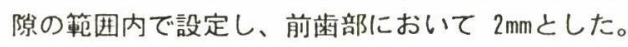
また被験者の限界運動を可及的に変化させないよう咬 合調整を行なった（図 1)。

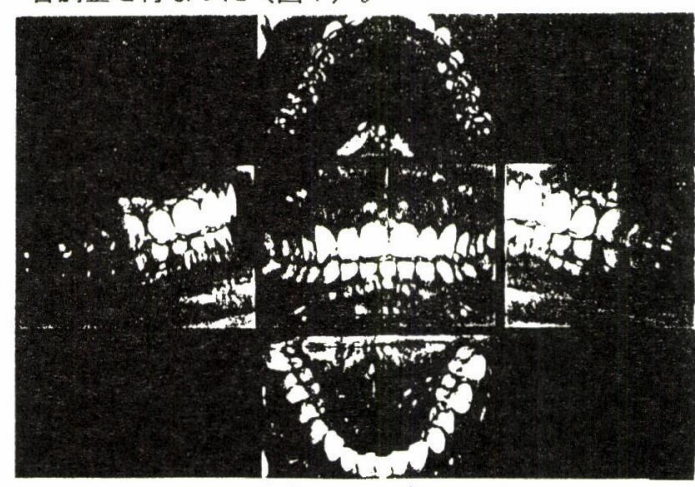

図 1 垂直的ガイダンス設定装置 


\section{3 記録方法}

被験者に偏心限界運動及び当教室にて独自に作成し た約 400語からなる日本語被験文を同一日に3回朗読 させ、被験文朗読時の下領切歯点運動をシロナソグラ フ・アナライジング・システムIII（カノープス電子

（株）、神戸・東京歯科産業（株）、東京・シーメン ス、ドイツ) を用いて、装置装着前・装着直後・装着 24時間後（撤去直前）・撤去直後・撤去 7日後と計 8 日間を実験期間として記録した。

\section{4 被験文}

被験文は、五十音すへてての語を含み、可及的に下額 運動を大きく行わせるために上下、前後、側方偏位量 の大きい語と小さい語とを組合わせ、また前䨑被蓋と 関係が深いと䓂われている「さ」行の語を多く含むも ので、NHK大阪放送局元チーフアナウンサーの協力 のもとに独自に作成した（表 1)。

\section{表 1 被験文}

もかしも加しのおけなしです。るところにおじいさんとおばあさんが いせした。こどもがいるくて、たいへんさり゙しかったのてすが、ふたりは、 なかよく、くらしていました。おしいさんは、それはそれは、溡たらきもの てした。

おおさかだいがくしいっしんのささきすすもさんは、すくれたそしつを そなえたしんしんさっ加たささくくるにさそって、しんさくをしばいかする こうそうを、すすめさせよう。

うみにち加い、しんちくのいいうちにすむきみには、いんしょうはのうぐいす いろのいいえをまくろうとおもう。

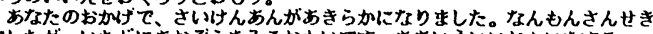
てしたが、いちどにおだらをみるおもいてす。ああいういいおもいをする ことは、らとにもさきにも、もうないてしよう。

しずずと、ししんてんにすすむれたあきしののみやさまときこさまは、 ひろびろとしたにわのいしがきにるていきいきとさくきくのはなのまて しばしたちどまられた。

\section{5 分析方法}

発語時下額運動を分析するに際して、装置装着前に は被験者本来の咬頭棪合位を、装置装着時には装置に より新たに与えられた咬頭貯合位を原点とした。また 発語時下额運動の概形楾を運動域境界とし、下額運動 域境界で囲まれた部分を運動域とし、以下に示す分析 項目について検討した（表 2)。

(1)発語時下額運動域境界上の代表点の座標及び運動 域幅径

下預運動域境界上の代表点として、最上方点、最下 方点、最前方点、最後方点、最右側点、最左侧点の 6 点を選択しその三次元的座標を求めた。また運動域の 最大上下幅、前後幅、左右幅を計測した（図2）。

(2) 発語時下預運動軌跡の分布密度

発語時下頡運動軌跡の分布密度に関して、運動轨跡! を咬頭瞆合位より下方 $2.5 \mathrm{~mm}$ で上下に分けた。分布密! 度として各領域に含まれるサンプリングボイント数の
運動域中の全サンブリングボイント数に対する比率を 求めた（図了）。

(3) 発語時下額運動の平均速度

発語時下疑運動の平均速度（以下平均速度とする） に関して下頜運動を上、下、前、後、右、左、の 6 方 向に分け、各方法に関してそれぞれ平均速度を求めた (図4)。

以上(1)(2)(3の分析項目について装置装着前の状態を 基準とし、おのおのの時期についてそれぞれPaired ttestにて検討した。また装置装着前の分析值の各被験 者 3回の記録の平均值 \pm 1 S. D. を基準とし、その基準 以上あるいは以下である場合を各被駼者の変化として、 過半数の被験者に認められる変化の傾向を検討した。

\section{表 2 分析項目}

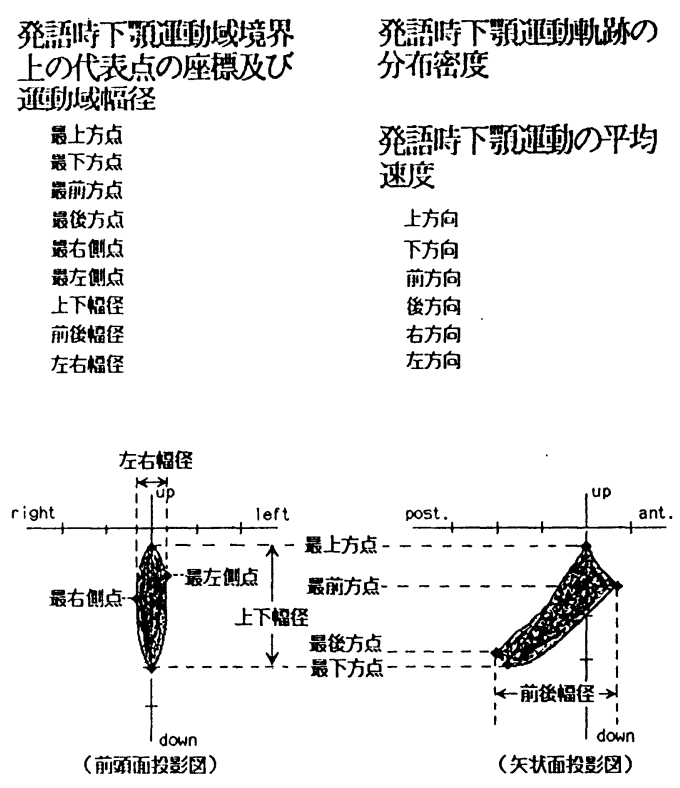

図2 発語時下額運動域境界上の代表点 及び運動域幅径

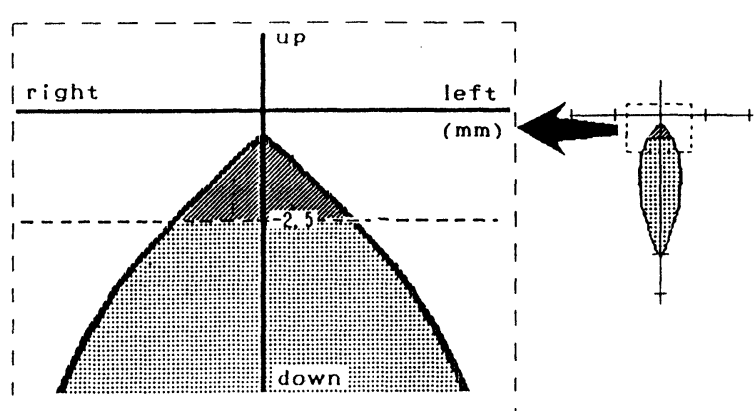

図3 発語時下㯋運動軌跡の分布密度 


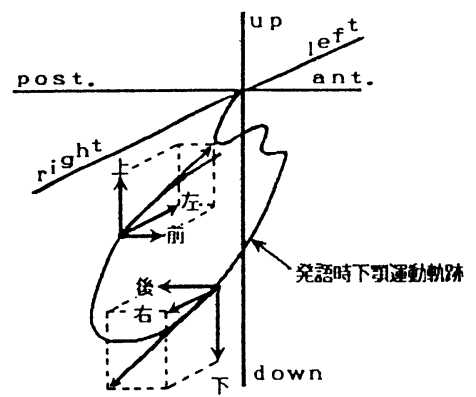

図4発語時下䫈運動の平均速度

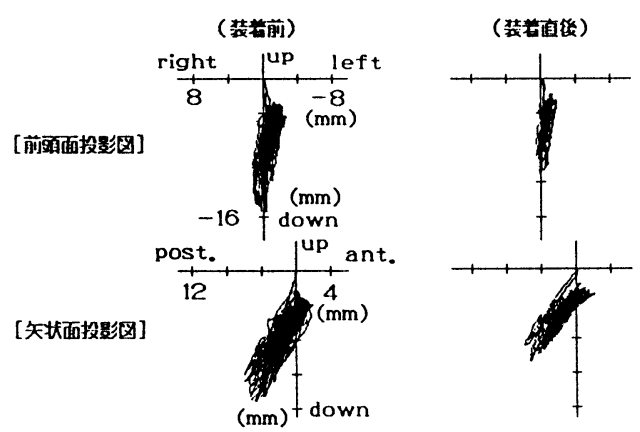

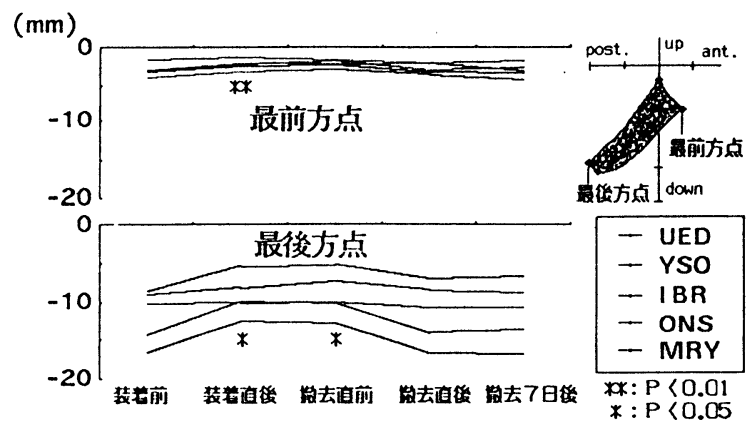

図7発語時下頙運動域境界上の前後座標

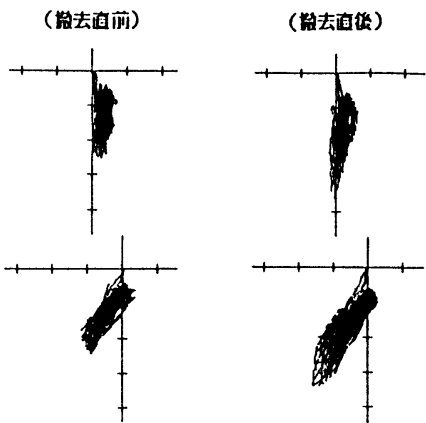

(去7日低)

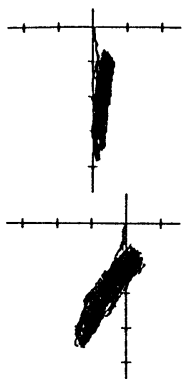

図 5 咬合高径による発語時下䇗運動変化の一例

III 战果

1、肉眼的観察について

肉眼的観察において運動域は装置装着前と比較し装 着後に小さくなり、撤去後に装着前の大きさに戻る傾 向が認められた（図5）。

2、分析項目について

(1運動域境界上の代表点の座標及び運動域幅径

上下座標において最上方点では撤去直前に、最前方 点では装着直後に、最後方点、最下方点では装着直後 及び撤去直前に、装䈯着前と比較して有意に上方へ の変化が認められた（図6、7）。

前後、左右座標においては、すべての点で装置装着 による変化は認められなかった（表 3 ）。
表 3 発語時下額運動域境界上の代表点

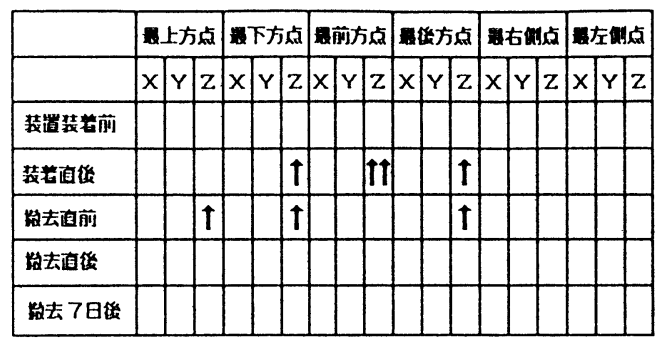

T坊: $\mathrm{P}<0.01 \uparrow$ 上方: $\mathrm{P}<0.05$

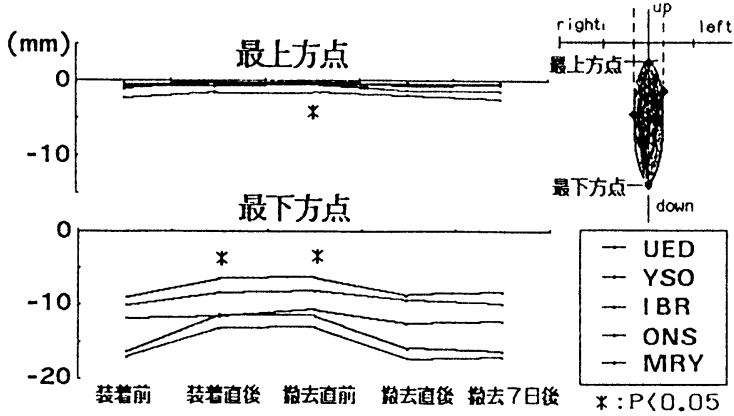

図6 発語時下䫈運動域境界上の上下座標

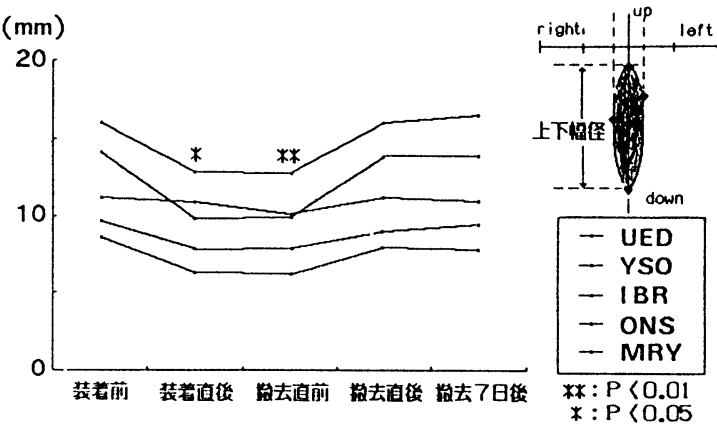

図 8 発語時下䫈運動域の上下幅径 
上下、前後幅径では、装固装着前と比較し装着直後、 撤去直前に有意に減少した（図 8、9）。

左右幅径に関しては装宣による变化は認められなか った（表4）。
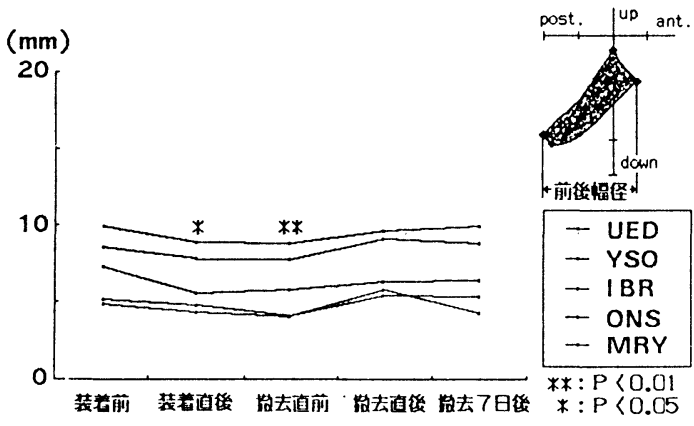

図 9 発語時下㯋運動域の前後幅径

\section{表 4 発語時下額運動域の幅径}

\begin{tabular}{|c|c|c|c|}
\hline & 上下幅径 & 前後幅佳 & 左古幅徍 \\
\hline 装置猿落前 & & & \\
\hline 装曾直後 & $\downarrow$ & $\downarrow$ & \\
\hline 去直前 & U & $\amalg$ & \\
\hline 去面後 & & & \\
\hline 执去7日後 & & & \\
\hline
\end{tabular}

(2) 発語時下額運動軌跡の分布密度

装置装着前と比較して装着直後に上部は增加し、下 部は減少する傾向が証めらた。また撤去直後に装着直 前の状態に戻る傾向が認められた（図10、表5）。
表 5 発語時下䫈運動軌跡の分布密度

\begin{tabular}{|c|c|c|}
\hline & 上部 & 下部 \\
\hline \multicolumn{3}{|l|}{ 装置装着前 } \\
\hline 装着直後 & $\uparrow$ & $\downarrow$ \\
\hline 去直前 & $\uparrow$ & $\downarrow$ \\
\hline \multicolumn{3}{|l|}{ 放去画业 } \\
\hline 散去7日绕 & & \\
\hline
\end{tabular}

\section{（3）発語時下顁運動の平均速度}

上下、前後方向において装置装着により減少する傾 向があったものの下方向の撤去直前のみに有意差が認 められた。また撤去後は被験者間に差はあるものの徐 々にもとに戻る傾向が認められた（図１１，12）。 左右方向においては装置装着による变化は認められな かった（図13、表6）。

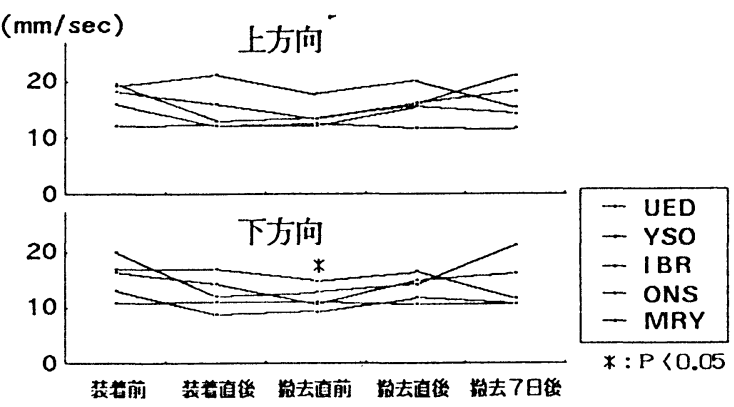

図１1発語時下顥運動の平均速度

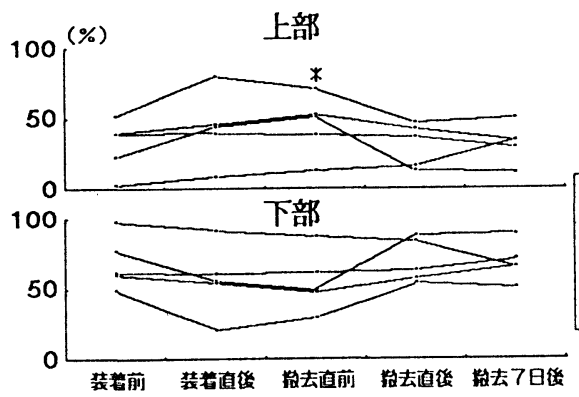

図10 発語時下㯋運動軌跡の分布密度

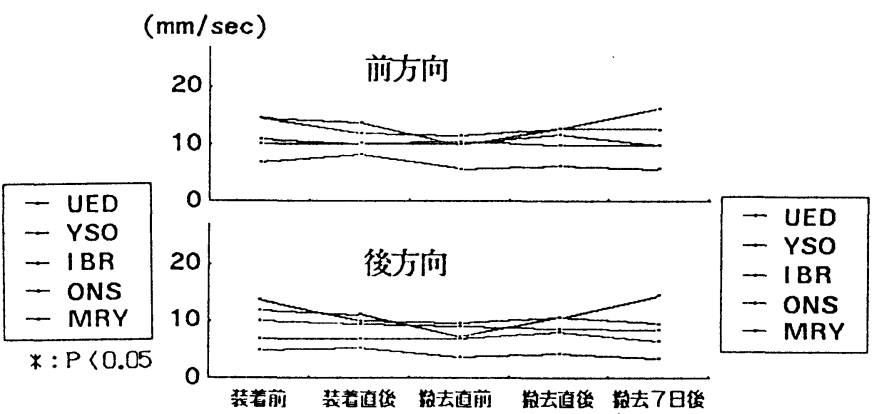

図12 発語時下額運動の平均速度 


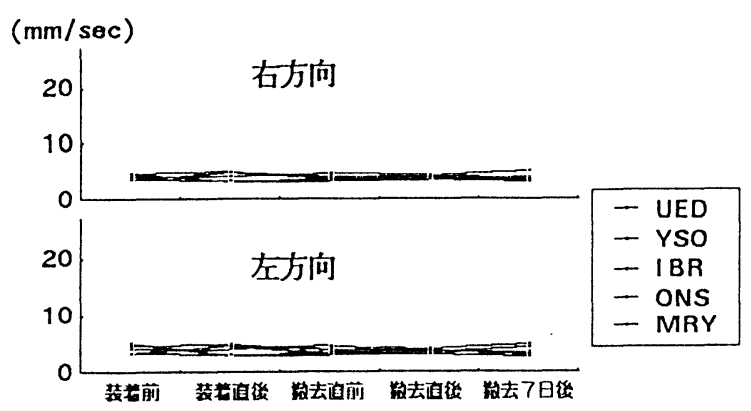

図１3 発語時下顎運動の平均速度

表 6 発語時下㯋運動の平均速度

\begin{tabular}{|c|c|c|c|c|c|c|}
\hline & 上 & 下 & 前 & 溇 & 右 & 左 \\
\hline \multicolumn{7}{|l|}{ 装置装者前 } \\
\hline 䔉者面後 & $\downarrow$ & $\downarrow$ & $\downarrow$ & $\downarrow$ & & \\
\hline 去自前 & $\downarrow$ & $\downarrow$ & $\downarrow$ & $\downarrow$ & & \\
\hline 放去面谖 & $\downarrow$ & 1 & $\downarrow$ & $\downarrow$ & & \\
\hline 第去7日後 & $\downarrow$ & $\downarrow$ & $\downarrow$ & $\downarrow$ & & \\
\hline
\end{tabular}

$\downarrow$ 娍少: $\mathrm{P}<0.05$ 減少偭向

IV 考察

1 方法について

（1）被験者について

本研究において咬合挙上を行うために上頻に装置を 装着しているか、、咬合挙上による影㖕のみではなく、 咬合面形態の変化による影響の可能性を考虑にいれ、 今回は被駼者の咬合様式が犬歯誘導を有するもののみ を選択した。これは犬歯誘導が 1 歯対 1 崡の接触にて 離開し、その離開角度のみの再現でよいために比較的 本来の限界運動の再現が容易であると判断したからで ある。

（2）実験装置について

被験者は有歯頜者であるため、実験的に咬合挙上を 行なうためには、歯列咬合面上に举上装置を設圈する 必要があり、従来の実験においてはレジン製スプリン 卜を用いた方法が行なわれてきたが9.10１11１2１31， 今回は装置により垂直的にのみ変化させ、装置自体の 影響を極力混入させないため咬合面を可及的に本来の 咬合面形態を再現した装軍を作製した。装置による咬 合举上量は、被験者が個性正常咬合者であり装置装着
により侵害的影響を最小限するため、また日常臨床に おいて咬合高径を変化さす場合に安静空隙量が利用さ れることを考虑に入れ、被験者全員の安静空隙内であ る $2 \mathrm{~mm}$ と定めた。

（3）被験文について

従来より、発語機能を診查する際、単音を用いた報 告が多かっだ.10.11か、今回発語をより動的、生理 的な運動として評価するためには、連続音で構成され る文章朗読時の下穎運動を捉える必要がある3.4.5) と 考え、発語時下疑運動が取り得る全ての下額位を網羅 2) し、可及的に下顥運動が大きくなる組合わせの語を 含む被験文を作成した。

2 䊅果について

本実験において運動域に関しては上下座標、上下及 び前後幅径に変化が認められた。

上下座標に関して装亘装着前には被験者本来の咬頭 瞆合位を、装置装着時には装冝により新たに与えられ た咬頭的合位を原点として比較した場合、最上方点、 最下方点とも上方への変化が認められたが、装置装着 前後とも原点を被験者本来の咬頭晼合位で比較した場 合、最下方点の上下座標について有意な差は認められ ず、また最上方点の上下座標については有意に下方へ の変化が認められた。すなわちこの䊅果より発語時の 最大開口度は、被験者本来の咬頭嵌合位を開口開始点 として一定で、咬合を举上することにより上方への運 動が規制されるため運動域の上下幅径が減少すると考 えられる。分布密度に関しても上方への規制により上 部が增加する傾向が認められたと考えられる。運動域 が装置装着後に上下、前後に小さくなる、すなわち運 動距離が減少することにより速度も滅少すると考えら れる。

\section{V 䊅論}

発語時下頴運動に咬合高径が及ぼす影啐を明らかに することを目的として、実験的に咬合高径を举上する 装苦の装着及び撤去による発語時下顎運動の変化を検 討したところ以下の結果が得られた。

1）発語時下额運動域に関して

装置装着により運動域は上下、前後に小さくなり、 撤去直後に装着前の状態に戻った。

2）発語時下額運動軌跡の分布密度について

装置装着により上部の分布密度は增加する倾向か、 下部の分布密度は減少する傾向があり、撤去直後から 徐々に装道装着前の状態に戻る傾向があった。

3）発語時下預運動の平均速度について

装置装着により上下、前後方向の平均速度は減少す 
る傾向が認められ、撤去直後から徐々に装着前の状態 に戻る傾向があった。

VI 参考文献

1) 丸山用郎：臨床生理咬合、医䔀薬出版、東京、1988.

2) 吉岡慎郎、小河弘枝、桑原俊也、宮内修平、丸山㓮 郎：発語における下㯋運動に関する補籺学的研究、 第 1 報 五十音発語時の下頜位について、補緅誌、 $36: 817-822 、 1992$.

3) 小河弘枝、吉岡慎郎、三間修司、桑原俊也、宮内佟 平、丸山㴊郎：発語時下㯋運動の恒常性に関する研 究、阪大誌、37:539-546.

4) 吉岡慎郎：発語時下預運動における咬合の影響に関 する補槡学的研究、阪大誌投稿中、

5) T. KUWAHARA, C. YOSHIOKA, H. OGAWA, S. MIYAUCHI, T. MARUYAMA: Effect of malocclusion on mandibular movements during speech, J. Dent. Res. 70 (Special Issue) :539, 1991

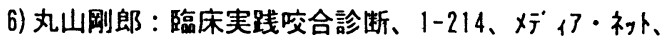
大阪、1989.

7) 丸山㴊郎：咀嗗運動の臨床制御とその異常、クイテデセ \%R, $11:$ 1992-2273、1992.

8) 荊木理惠子、山田真一、桑原俊也、瑞森崇弘、高島 史男、丸山用郎：咬合高径の変化が咀唃運動に及ぼ 寸影響、補籺誌、36 1273-1278、1992.

g) Silverman, M. M. : The speaking method in measuring vertical dimension. J. Prosthet. Dent., 193-19 9、 1952.

10) 萀田淳司、市川哲雄、松本直之 : 咬合高径の変化 が発音時の舌運動と下預運動に及ぼす影䍃、第 1 報 正常有齿預者、補棳誌、35：67-79、1991.

11) 薦田淳司、市場裕康、市川哲雄ほか：咬合高径の 变化が発音時の舌運動と下㯋運動に及ぼす影響、 第2 報 全部㭲義歯装着者、補緅誌、 $35 ： 418-43$ 1. 1991.

12) Hardmann, G. Proeschal, P. und Ott, R. W. : Kaukraefte und maximale kiefershlies zkraefte von totalprothesentragern vor und nach biszhebung. Dtsch Zahnaerztl Z, $44:$ 26-29, 1989.

13) 河野正勝：咬合举上とリズムの変化がEMGの時間的 要素へ及ぼす影箁について、日大歯学、55:434-4 47. 1981. 